\title{
Comparison of Pure Nicotine- and Smokeless Tobacco Extract-Induced Toxicities and Oxidative Stress
}

\author{
D. Yildiz, Y.-S. Liu, N. Ercal, D. W. Armstrong \\ Department of Chemistry, University of Missouri-Rolla, Rolla, Missouri 65401, USA
}

Received: 14 September 1998/Accepted: 24 February 1999

\begin{abstract}
The toxicities and oxidative stress-inducing actions of (-)-nicotine and smokeless tobacco extract (STE), containing equivalent amounts of nicotine, were studied. Toxicities were determined by colony formation assays using Chinese hamster ovary $(\mathrm{CHO})$ cells. Results indicated that nicotine is less toxic than smokeless tobacco extract that contained the same amount of nicotine. The generation of reactive oxygen species, following treatment with smokeless tobacco extract and nicotine, was assessed by measurement of changes in glutathione (GSH) and malondialdehyde (MDA) levels. $\mathrm{CHO}$ cells $\left(5 \times 10^{5}\right.$ cells $/ 5 \mathrm{ml}$ media $)$ were incubated with $4,0.8$, and $0.08 \mathrm{mg}$ of nicotine and STE containing the same amounts of nicotine. All preparations of smokeless tobacco extract significantly decreased GSH levels and increased MDA generation. However, $0.08 \mathrm{mg}$ of nicotine treatment did not result in a significant change in GSH level, and only $4 \mathrm{mg}$ of nicotine were sufficient to increase MDA generation. Addition of free radical scavenging enzymes, superoxide dismutase (SOD) and catalase (CAT), and an intracellular GSH precursor, N-acetyl-L-cysteine (NAC), replenished the GSH levels in nicotine-treated cells. GSH levels in cells exposed to smokeless tobacco extract containing 4 and $0.8 \mathrm{mg}$ nicotine remained significantly lower than the control with the addition of SOD and CAT. However, co-addition of NAC with smokeless tobacco extract preparations returned the GSH levels to the control level. Lactate dehydrogenase (LDH) activities were measured in the media to establish the membrane damage following exposure to smokeless tobacco extract and nicotine. Treatment of cells with $4 \mathrm{mg}$ nicotine caused a significant increase in LDH activity, which was returned to control level in the presence of the antioxidant enzymes and NAC. Smokeless tobacco extract did not change the LDH activity.
\end{abstract}

The effects of an aqueous extract of smokeless tobacco and nicotine have been extensively studied in separately designed in vivo and in vitro experimental systems using either nicotine or smokeless tobacco extract (Schievelbein 1982; Christen et al. 1990; Gross et al. 1995). Alteration of heat shock protein

Correspondence to: N. Ercal production (Bagchi M et al. 1995; Hahn et al. 1991), inhibition of cell metabolism and proliferation (Konno et al. 1991; Waggoner and Wang 1994), and induction of nuclear aberrations (Livingstone et al. 1990; Doolittle et al. 1995) are some of the common results of smokeless tobacco extract and nicotine administration. In addition, it has been demonstrated that both nicotine and smokeless tobacco administration result in generation of reactive oxygen species in in vitro experimental systems (Bagchi D et al. 1995; Wetscher et al. 1995a). Treatment of rat peritoneal macrophage and J774.1 macrophage cells in a culture with smokeless tobacco extract has been shown to induce nitric oxide production (Hassoun et al. 1995) and generation of free radicals in other experimental systems (Bagchi et al. 1996). In similar sets of experiments, nicotine has also been shown to induce free radical generation, as evidenced by changes in intracellular oxidative stress parameters such as glutatione (GSH) and malondialdehyde (MDA) (Wetscher et al. 1995b; Ashakumary and Vijayamal 1996; Yildiz et al. 1998).

Some of the biological and physiological endpoints of tobacco consumption have been attributed to its major alkaloid, nicotine (Connolly et al. 1986; Benowitz 1988). However, there has not been any study directly comparing the extent of the effects of nicotine and smokeless tobacco extract on the same biological parameters. Therefore, the objective of this study was to compare the effects of pure nicotine and smokeless tobacco extract, containing the same amount of nicotine, induced toxicities and oxidative stress. The study also investigated the effects of antioxidant enzymes and of N-acetyl-Lcysteine (NAC) on nicotine- and smokeless tobacco extractinduced toxicity and oxidative stress.

\section{Materials and Methods}

Chinese hamster ovary $(\mathrm{CHO}) \mathrm{K} 1$ cells were obtained from American Type Culture Collection (Rockville, MD). The items required for the maintenance of cell cultures, Ham's F-12 media, fetal calf serum (FCS), and glutamine were obtained from Sigma Chemical Company (St. Louis, MO). Catalase (CAT), superoxide dismutase (SOD), lactate dehydrogenase $(\mathrm{LDH})$, and (-)-nicotine were also purchased from Sigma. N-(1-pyrenyl)-maleimide (NPM) was purchased from Aldrich Chemical Company (St. Louis, MO). Bradford reagent was obtained from BioRad (Melville, NY). The HPLC-grade reagents were purchased from Fisher Scientific (St. Louis, MO). Smokeless tobacco was 
obtained from University of Kentucky, Tobacco and Health Research Institute (Lexington, KY).

\section{Preparation of Smokeless Tobacco Extract and Quantitation of Nicotine Content}

Extraction: Chewing tobacco $(80 \mathrm{~g})$ was cut into small pieces and stirred in distilled water $(300 \mathrm{ml})$ for $24 \mathrm{~h}$ in the dark at room temperature. The mixture was filtered and the filtrate was centrifuged at $4,000 \mathrm{~g}$ for $1 \mathrm{~h}$. The supernatant fraction was filtered through a millipore filter $(0.45 \mu \mathrm{m})$ and frozen, then put onto a freeze-drier. The sample was not taken to dryness, but was stopped and then thawed to give $60 \mathrm{ml}$ of solution. $\mathrm{NaOH}$ ( $1 \mathrm{ml}$ of $1 \mathrm{~N}$ solution) was added to $1 \mathrm{ml}$ of the above solution. The mixture was extracted with ether $(4 \mathrm{ml})$ until additional extraction did not show any nicotine peak by gas chromatography (usually this occurred by five extractions). An internal standard of $1 \mathrm{ml}$ ( $50 \mathrm{mM}$ anthranilamide in methanol) was added to the combined etheral extract, and the mixture was concentrated on a water bath at $45^{\circ} \mathrm{C}$ to about $2 \mathrm{ml}$ (Raisi et al. 1986).

Equipment: Analyses were carried out on a Hewlett Packard (Corvallis, OR) model 5890 series II gas chromatograph equipped with a flame ionization detector and HP 3396 series II integrator. The column was a DB5 (J\&W Scientific, $30 \mathrm{~m} \times 0.25 \mathrm{~mm}$ ID, $0.25 \mu \mathrm{m}$ film thickness). Helium was used as the carrier gas. The temperatures for injector and detector were set at $220^{\circ} \mathrm{C}$ and $250^{\circ} \mathrm{C}$, respectively. A split ratio of about 100/1 was used for all the analyses. Nicotine and the internal standard in the sample extract were eluted from the column as sharp and symmetrical peaks within 12 and $20 \mathrm{~min}$, respectively.

Calibration Curve: A calibration curve for nicotine was constructed over a range of $20-100 \mathrm{mM}$ of nicotine in water. The data were subjected to linear regression analysis to give the appropriate calibration factor. The calibration curve was found to be linear over the range of concentrations 20-100 mM (correlation coefficient 0.996).

\section{Cells and Culture Conditions}

CHO cells were propagated in Ham's F-12 culture media supplemented with $10 \% \mathrm{FCS}$ and maintained at $37^{\circ} \mathrm{C}$ in a humidified atmosphere of $5 \% \mathrm{CO}_{2}$ and $95 \%$ air.

\section{Colony Formation Assay}

For colony formation assay, exponentially growing cultures were detached from the surface by trypsinization, and the cell suspension was centrifuged at 2,000 $g$ for $5 \mathrm{~min}$. The resulting cell pellets were resuspended in fresh media and counted on a hemocytometer. Between 100 and 1,000 cells were seeded into small $(60-\mathrm{mm})$ petri dishes in $5 \mathrm{ml}$ media and incubated for $4 \mathrm{~h}$ to allow cell attachment to the surface. Nicotine and smokeless tobacco extract were then added to the petri dishes. The cells were then incubated for 7 days in the presence of nicotine and smokeless tobacco extract. At the end of incubation, colonies were stained and counted.

\section{Staining, Counting of Colonies, and Construction of Cell Survival Curve}

After the media was decanted carefully, crystal violet ( $1 \mathrm{~g}$ crystal violet dissolved in $400 \mathrm{ml}$ methanol prepared $50 \times$ staining solution) was added for $10 \mathrm{~min}$ to stain the colonies. The plates were washed with distilled water, allowed to air dry, and the number of colonies were then counted. The plating efficiency was calculated as follows: plating efficiency $=$ colonies counted/cells seeded $\times 100$. The survival fraction was calculated as follows: survival fraction $=$ colonies counted / cells seeded $\times$ (plating efficiency ${ }_{\text {control }} /$ 100) (Hall 1988).

\section{Oxidative Stress Studies}

Cells from exponentially growing cells were established $\left(5 \times 10^{5} / 5\right.$ $\mathrm{ml}$ media) in culture flasks. After $4 \mathrm{~h}$ of incubation to allow cell attachment, various concentrations of nicotine $(0.08 \mathrm{mg}, 0.8 \mathrm{mg}$, and 4 $\mathrm{mg}$ ) and smokeless tobacco extract containing the same amounts of nicotine were added to the media. Cells were then further incubated for $24 \mathrm{~h}$ in the presence of $(-)$-nicotine or smokeless tobacco extract. SOD (10 units $/ \mathrm{ml})$ and CAT (10 units $/ \mathrm{ml}$ ) or NAC ( $2 \mathrm{mM}$ ) were added along with nicotine and smokeless tobacco extract. At the end of the incubation, LDH activity was assayed in the media. The cells were trypsinized, collected, and homogenized for the determination of GSH and MDA levels.

\section{GSH and MDA Determination}

Details of the GSH and MDA measurements and of the HPLC systems were described in a previous study (Neal $\mathrm{R}$ et al. 1997). MDA levels were determined as described by Draper et al. (1993) and Esterbauer $e t$ al. (1991). The GSH numerical values for the different experiments varied due to GSH fluctuations. For this reason, we converted the numbers to percent control to represent the data more clearly.

\section{LDH Activity Assay}

The LDH activity assay was performed as described previously (Tietz 1986). For the LDH measurements in a cell free system, $3 \mu \mathrm{l}$ of LDH stock solution $(1,000 \mathrm{U} / \mathrm{ml})$ were added to the media $(5 \mathrm{ml})$ containing either nicotine or smokeless tobacco extract. Samples were then removed at 0-, 4-, and 24-h time intervals for the determination of LDH activities. For time 0 , samples were taken as soon as $\mathrm{LDH}$ was added to the media containing either nicotine or smokeless tobacco extract. $\mathrm{LDH}$ activities were then determined.

\section{Protein Determination}

The Bradford (1976) method was used to determine the protein content of the cell samples using coomassie blue and optical density determinations at $595 \mathrm{~nm}$.

\section{Statistical Analysis}

InStat by GraphPad software (San Diego, CA) was used to conduct a statistical analysis. One-way analysis of variance (ANOVA) and Student-Newman-Keuls multiple comparison tests were applied. Values of $\mathrm{p}$ less than 0.05 were considered to be significant.

\section{Results}

\section{Colony Formation}

Table 1 shows the survival fractions of nicotine- and smokeless tobacco extract-exposed cells in the presence and absence of 
Table 1. Survival fractions of $\mathrm{CHO}$ cells following exposure to nicotine and smokeless tobacco extract containing equivalent concentrations of nicotine

\begin{tabular}{|c|c|c|c|}
\hline \multirow[b]{2}{*}{ Groups $^{\mathrm{a}}$} & \multicolumn{3}{|c|}{ Survival Fractions } \\
\hline & $\begin{array}{l}\text { No } \\
\text { Antioxidant }\end{array}$ & $\begin{array}{l}\text { SOD and } \\
\text { CAT }\end{array}$ & NAC \\
\hline Control & \pm 0 & \pm 0 & \pm 0 \\
\hline $0.08 \mathrm{mg}$ nicotine & $0.90 \pm 0.09$ & $1.00 \pm 0.06$ & $0.80 \pm 0.04$ \\
\hline $\begin{array}{l}\text { Smokeless tobacco } \\
\text { extract containing }\end{array}$ & & & \\
\hline $0.08 \mathrm{mg}$ nicotine & $0.40 \pm 0.04$ & $0.80 \pm 0.07$ & $1.00 \pm 0.03$ \\
\hline $0.8 \mathrm{mg}$ nicotine & $0.80 \pm 0.10$ & $0.70 \pm 0.04$ & $0.60 \pm 0.03$ \\
\hline $\begin{array}{l}\text { Smokeless tobacco } \\
\text { extract containing } 0.8\end{array}$ & & & \\
\hline mg nicotine & 0 & 0 & $0.50 \pm 0.04$ \\
\hline $4 \mathrm{mg}$ nicotine & $0.03 \pm 0.01$ & $0.04 \pm 0.00$ & $0.04 \pm 0.00$ \\
\hline $\begin{array}{l}\text { Smokeless tobacco } \\
\text { extract containing } 4 \\
\text { mg nicotine }\end{array}$ & 0 & 0 & 0 \\
\hline
\end{tabular}

Details of the procedure are explained in the Materials and Methods section

Values represent the mean $\pm \mathrm{SD}$ of three separate experiments

${ }^{a}$ The final volume of cell culture media for control, nicotine, and smokeless tobacco extract groups was $5 \mathrm{ml}$

antioxidant enzymes and NAC. Incubation of CHO cells with nicotine and smokeless tobacco extract inhibited colony formation. Nicotine inhibited the colony formation $97 \%$ at $4 \mathrm{mg}$.

However, smokeless tobacco extract containing $0.08 \mathrm{mg}$ nicotine was sufficient to reduce the colony formation by more than half. At higher nicotine contents ( 0.8 and $4 \mathrm{mg}$ ), smokeless tobacco extract completely inhibited the colony forming ability of $\mathrm{CHO}$ cells. These results indicate that nicotine alone is less toxic than smokeless tobacco extract containing an equivalent amount of nicotine.

The administration of antioxidant enzymes and NAC along with nicotine improved the rate of colony formation for both nicotine and smokeless tobacco extract. NAC completely returned the survival fractions to the control level with smokeless tobacco extract containing $0.08 \mathrm{mg}$ nicotine. NAC also restored the colony-forming ability of the cells exposed to smokeless tobacco extract containing $0.8 \mathrm{mg}$ nicotine. However, it did not improve the colony formation with smokeless tobacco extract containing $4 \mathrm{mg}$ nicotine or analogous smokeless tobacco extract.

\section{GSH and MDA Measurement}

GSH levels in the presence and absence of antioxidant enzymes and NAC were determined after exposure for $24 \mathrm{~h}$ to nicotine and smokeless tobacco extract containing the same amount of nicotine. As shown in Table 2, all preparations of smokeless tobacco extract induced significant decreases in GSH levels. Nicotine exposure of the cells also resulted in a decrease in GSH levels. However, significant decreases were observed only with 0.8 and $4 \mathrm{mg}$ nicotine exposures. Although both nicotine and smokeless tobacco extract lowered the intracellular GSH contents of the cells, their efficiencies were considerably different with smokeless tobacco extract being more potent than
Table 2. GSH and MDA levels in CHO cells following exposure to nicotine and smokeless tobacco extract containing equivalent concentrations of nicotine

\begin{tabular}{|c|c|c|c|c|c|}
\hline Groups $^{\mathrm{a}}$ & $\begin{array}{l}\text { GSH } \\
\text { (\% Control) }\end{array}$ & $\begin{array}{l}\text { GSH with } \\
\text { SOD and } \\
\text { CAT } \\
\text { (\% Control) }\end{array}$ & $\begin{array}{l}\text { GSH With } \\
\text { NAC } \\
\text { (\% Control) }\end{array}$ & MI & \\
\hline Control & $100 \pm 29$ & $100 \pm 18$ & $100 \pm 12$ & & \pm 0.4 \\
\hline $0.08 \mathrm{mg}$ nicotine & $76 \pm 19^{b}$ & $87 \pm 5$ & $85 \pm 5$ & 10 & $\pm 2^{\mathrm{b}}$ \\
\hline \multicolumn{6}{|l|}{$\begin{array}{l}\text { Smokeless tobacco } \\
\text { extract containing }\end{array}$} \\
\hline $0.08 \mathrm{mg}$ nicotine & $38 \pm 14^{c}$ & $98 \pm 11$ & $91 \pm 6$ & 12 & $\pm 1^{\mathrm{c}}$ \\
\hline $0.8 \mathrm{mg}$ nicotine & $61 \pm 11^{b, c}$ & $103.0 \pm 0.4^{b}$ & $84 \pm 2$ & 8 & $\pm 1^{\mathrm{b}}$ \\
\hline \multicolumn{6}{|l|}{$\begin{array}{l}\text { Smokeless tobacco } \\
\text { extract containing }\end{array}$} \\
\hline $0.8 \mathrm{mg}$ nicotine & $24 \pm 1^{\mathrm{c}}$ & $40 \pm 2^{c}$ & $89 \pm 3$ & 12 & $\pm 1^{\mathrm{c}}$ \\
\hline 4 mg nicotine & $64 \pm 12^{\mathrm{b}, \mathrm{c}}$ & $90 \pm 5^{b}$ & $70 \pm 6^{c}$ & 12 & $\pm 1^{\mathrm{b}, \mathrm{c}}$ \\
\hline $\begin{array}{l}\text { Smokeless tobacco } \\
\text { extract containing }\end{array}$ & & & & & \\
\hline 4 mg nicotine & $5 \pm 1^{\mathrm{c}}$ & $22 \pm 10^{c}$ & $88 \pm 7$ & 19 & $\pm 1^{\mathrm{c}}$ \\
\hline
\end{tabular}

GSH levels are reported as \% control (nmol/mg protein). MDA levels are reported as nmol/100 mg protein. GSH was measured by NPM derivatization followed by HPLC. The thiobarbutiric acid derivative of MDA was identified by HPLC. Details of the procedure are explained in the Materials and Methods section. Values represent the mean $\pm \mathrm{SD}$ of three separate experiments

a The final volume of cell culture media for control, nicotine, and smokeless tobacco extract groups was $5 \mathrm{ml}$

${ }^{b}$ Significantly different from smokeless tobacco extract containing the same amount of nicotine

${ }^{\mathrm{c}}$ Significantly different from the corresponding control value

the corresponding nicotine concentration. Treatment of the cells with $4 \mathrm{mg}$ of nicotine resulted in a $36 \%$ decrease in GSH level as compared to control. However, there was a $95 \%$ decrease in GSH levels in cells exposed to smokeless tobacco extract containing $4 \mathrm{mg}$ of nicotine.

Coaddition of antioxidant enzymes returned the GSH levels to the control level in nicotine-exposed cells. These enzymes also increased the GSH levels in cells treated with smokeless tobacco extract containing $0.08 \mathrm{mg}$ nicotine. Although GSH levels in cells exposed to smokeless tobacco extract with higher nicotine contents remained significantly lower than the control in the presence of SOD and CAT, small increases in GSH levels were still observed. In contrast to SOD and CAT, coaddition of NAC with all preparations of smokeless tobacco extract returned the GSH levels to the control level. The GSH levels in cells treated with $4 \mathrm{mg}$ of nicotine remained significantly decreased in the presence of NAC. However, NAC returned the GSH levels to the control level in $0.8 \mathrm{mg}$ of nicotine-treated cells.

To determine if the decreases in GSH levels were associated with an increase in lipid peroxidation, the MDA contents were measured following exposure to nicotine and to smokeless tobacco extract. As shown in Table 2, significantly increased MDA levels were observed for both nicotine and smokeless tobacco extract that corresponded to the decreased GSH levels. Since employment of NAC and antioxidant enzymes already demonstrated that the effects observed were due to free radical generation, we did not evaluate the effects of NAC and antioxidant enzymes on MDA generation. 
Table 3. LDH activities in the media following exposure to nicotine and smokeless tobacco extract containing equivalent concentrations of nicotine

\begin{tabular}{|c|c|c|c|}
\hline Groups $^{\mathrm{a}}$ & $\begin{array}{l}\text { LDH } \\
\text { Activity }\end{array}$ & $\begin{array}{l}\text { LDH Activity } \\
\text { with SOD } \\
\text { and CAT }\end{array}$ & $\begin{array}{l}\text { LDH Activity } \\
\text { with NAC }\end{array}$ \\
\hline Control & $47 \pm 2$ & $47 \pm 2$ & $54 \pm 6$ \\
\hline $0.08 \mathrm{mg}$ nicotine & $58 \pm 6$ & $52 \pm 4$ & $48 \pm 4$ \\
\hline \multicolumn{4}{|l|}{$\begin{array}{l}\text { Smokeless tobacco } \\
\text { extract containing }\end{array}$} \\
\hline $0.08 \mathrm{mg}$ nicotine & $52 \pm 8$ & $51 \pm 1$ & $62 \pm 5$ \\
\hline $0.8 \mathrm{mg}$ nicotine & $56 \pm 8$ & $55 \pm 1$ & $50 \pm 6$ \\
\hline \multicolumn{4}{|l|}{$\begin{array}{l}\text { Smokeless tobacco } \\
\text { extract containing }\end{array}$} \\
\hline $0.8 \mathrm{mg}$ nicotine & $55 \pm 5$ & $50 \pm 1$ & $55 \pm 4$ \\
\hline 4 mg nicotine & $67 \pm 5^{b}$ & $54 \pm 1$ & $57 \pm 5$ \\
\hline \multicolumn{4}{|l|}{$\begin{array}{l}\text { Smokeless tobacco } \\
\text { extract containing }\end{array}$} \\
\hline 4 mg nicotine & $43 \pm 2$ & $43 \pm 7$ & $63 \pm 3$ \\
\hline
\end{tabular}

LDH activity is reported as unit/L. Details of the procedure are explained in the Materials and Methods section. Results represent the mean $\pm \mathrm{SD}$ of three separate experiments

a The final volume of cell culture media for control, nicotine, and smokeless tobacco extract groups was $5 \mathrm{ml}$

b Significantly different from the control

Table 4. Effects of nicotine and smokeless tobacco extract on LDH activity in a cell-free in vitro system

\begin{tabular}{llll}
\hline Groups & $\begin{array}{l}\text { LDH Activity } \\
(0 \mathrm{~h})\end{array}$ & $\begin{array}{l}\text { LDH Activity } \\
(4 \mathrm{~h})\end{array}$ & $\begin{array}{l}\text { LDH Activity } \\
(24 \mathrm{~h})\end{array}$ \\
\hline $\begin{array}{l}\text { Control } \\
0.08 \text { mg nicotine }\end{array}$ & $593 \pm 32$ & $583 \pm 17$ & $545 \pm 70$ \\
$\begin{array}{l}\text { Smokeless tobacco } \\
\text { extract containing }\end{array}$ & & $572 \pm 17$ & $618 \pm 39$ \\
$\quad 0.08$ mg nicotine & $593 \pm 45$ & $565 \pm 9$ & $578 \pm 54$ \\
$\begin{array}{l}\text { 0.8 mg nicotine } \\
\text { Smokeless tobacco } \\
\quad \text { extract containing }\end{array}$ & $596 \pm 38$ & $579 \pm 20$ & $600 \pm 8$ \\
$\quad 0.8$ mg nicotine & $557 \pm 40$ & $571 \pm 13$ & $615 \pm 20$ \\
$\begin{array}{l}\text { 4 mg nicotine } \\
\text { Smokeless tobacco } \\
\quad \text { extract containing }\end{array}$ & $606 \pm 16$ & $570 \pm 17$ & $611 \pm 10$ \\
$\quad 4$ mg nicotine & $420 \pm 12^{\mathrm{a}}$ & $419 \pm 15^{\mathrm{a}}$ & $394 \pm 46^{\mathrm{a}}$ \\
\hline
\end{tabular}

LDH activity is reported as units/L. Details of the procedure are explained in the Materials and Methods section. Values represent the mean \pm SD of three separate experiments

${ }^{a}$ Significantly different from the control

\section{LDH Activity Measurements}

LDH activities in the media of nicotine- and smokeless tobacco extract-exposed cells were determined at the end of the 24-h incubation time. As shown in Table 3, only $4 \mathrm{mg}$ of nicotine caused a significant increase in LDH activity. Treatment of cells with smokeless tobacco extract caused no statistically significant change in LDH activities in the media. LDH activities were also determined in the presence of the antioxidant enzymes and NAC. The presence of antioxidant enzymes and NAC restored the LDH activity to the control level in the media of $4 \mathrm{mg}$ nicotine-treated cells. LDH activities in smokeless tobacco extract-treated cells, in the presence of the antioxidant enzymes and NAC, still remained in the range of control LDH activity. The numerical values were not statistically different.

To test if smokeless tobacco extract or nicotine has any direct effect on the LDH enzymatic activity, we incubated the enzyme in a cell-free media in the presence of nicotine and smokeless tobacco extract for 24 hs. As shown in Table 4, only smokeless tobacco extract containing $4 \mathrm{mg}$ nicotine reduced the $\mathrm{LDH}$ activity significantly in a cell free environment. This inhibition occurred as soon as the enzyme was added to the media containing smokeless tobacco extract and the extent of inhibition did not change for $24 \mathrm{hs}$. The other preparations of smokeless tobacco extract and nicotine did not cause any change in $\mathrm{LDH}$ activities.

\section{Discussion}

The present results indicate that nicotine is considerably less toxic than smokeless tobacco extract containing the same amount of nicotine. These profound differences between nicotine and smokeless tobacco extract must result from, in addition to nicotine, the large numbers of other biologically active compounds that adversely affect the cell survival. It has been reported that tobacco contains, besides nicotine, tobaccospecific $\mathrm{N}$-nitrosamines formed during curing and fermentation of tobacco from nicotine and other alkaloids such as nornicotine, anatabine, and anabasine (Brunnemann et al. 1996). Some of the tobacco-specific N-nitrosamines have been shown to be metabolically activated in mammalian cells, leading to the formation of highly reactive electrophiles that react with nucleophilic molecules of the cells (Hoffmann and Hecht 1988). The presence of tobacco-specific N-nitrosamines and various carcinogenic compounds such as benzo[a]pyrene in tobacco may explain the smokeless tobacco extract's greater inhibitory effect on colony formation compared to nicotine alone.

Our present GSH and MDA data suggest that generation of free radicals may contribute to both nicotine and smokeless tobacco extract toxicity. Both nicotine and smokeless tobacco extract significantly increased MDA generation and reduced intracellular GSH levels, which were either partially or completely returned to control levels in the presence of free radical-scavenging enzymes and NAC. However, neither NAC nor the antioxidant enzymes had a significant protective effect on nicotine-induced inhibition of colony formation. These results indicate the presence of other mechanism(s) contributing to nicotine toxicity. In addition to free radical generation, one possibility is that constant exposure of the cells to nicotine for a long time overrides protection by the antioxidant enzymes, and NAC and toxicity become a result of nicotine-induced genotoxic effects. NAC and antioxidants cannot protect the cells from nicotine-induced genotoxic effects that become effective with overextended time period. In contrast to nicotine, employment of the free radical-scavenging enzymes and, particularly, NAC, with smokeless tobacco extract displayed a more protective effect, suggesting an important role for GSH depletion and oxidative stress in smokeless tobacco extract toxicity.

Induction of oxidative stress by both nicotine and smokeless tobacco extract has been demonstrated previously in separate experimental systems (Ashakumary and Vijayammal 1996; 
Bagchi et al. 1996). One of the main objectives of this study was to compare nicotine- and smokeless tobacco extractinduced oxidative stress by measuring GSH and MDA levels. The lower GSH and higher MDA levels in smokeless tobacco extract-exposed cells, as compared to nicotine-exposed cells, suggest that nicotine alone is less efficient in induction of oxidative stress than smokeless tobacco extract containing the same amount of nicotine. This indicates the presence of other compounds besides nicotine in smokeless tobacco extract that are involved in free radical generation. Addition of antioxidant enzymes and NAC increased the GSH levels in the presence of smokeless tobacco extract and nicotine. However, the responses of nicotine and smokeless tobacco extract-treated cells to antioxidant enzymes or NAC were different. In nicotineexposed cells, GSH levels were more efficiently restored in the presence of antioxidant enzymes as compared to the presence of NAC. In contrast, in smokeless tobacco extract-exposed cells, GSH levels were more efficiently restored in the presence of NAC as compared to the presence of antioxidant enzymes. These results suggest that the nature of free radicals generated or the mechanism of GSH depletion in nicotine and smokeless tobacco extract-treated cells is different, which further indicates that some of the nicotine-specific actions could be blocked in smokeless tobacco extract due to complex interactions among the constituents of smokeless tobacco extract.

In contrast to NAC, SOD and CAT cannot cross the cell membranes. Therefore, increases in GSH levels by SOD and CAT of nicotine-treated cells suggest that free radicals are generated or are present outside of the cells and are more efficiently scavenged by these enzymes rather than NAC. In contrast, the increase in GSH levels by NAC in smokeless tobacco extract-exposed cells suggests that free radicals are mainly present inside the cells and are more efficiently scavenged by the presence of NAC rather than SOD and CAT. Another possibility is that the GSH of the smokeless tobacco extract-exposed cells is also depleted by conjugation reactions with components and/or metabolites of smokeless tobacco extract. In this respect, NAC may replace GSH in conjugation reactions and directly activate GSH synthesis or directly scavenge the free radicals formed following exposure to smokeless tobacco extract, thereby replenishing the GSH levels to the control level.

Lipid peroxidation is known to disturb the integrity of cellular membranes, leading to the leakage of cytoplasmic enzymes, such as LDH, into the media (Bagchi D et al. 1995). To show the extent of membrane damage by nicotine and smokeless tobacco extract, the LDH activities were measured in the media. LDH activity was increased only in the media of 4 mg nicotine-treated cells. Although 4-mg-nicotine-containing smokeless tobacco extract resulted in generation of higher MDA levels, it did not increase the LDH activity in the media. This indicates that smokeless tobacco extract either prevents LDH leakage or contains an inhibitor of the enzyme. To test the possibility that smokeless tobacco extract may contain an inhibitor for the LDH enzymatic activity, we determined the changes in LDH activities in the presence of smokeless tobacco extract in a cell free system. Results showed that smokeless tobacco extract containing $4 \mathrm{mg}$ nicotine significantly inhibits the LDH activity. This may be sufficient to explain the absence of LDH activity in the media of cells treated with smokeless tobacco extract containing $4 \mathrm{mg}$ nicotine. However, smokeless tobacco extract containing $0.8 \mathrm{mg}$ nicotine, which had no effect on LDH activity in a cell-free system, generated the same amount of MDA as $4 \mathrm{mg}$ nicotine. Therefore, it is still not possible to completely attribute the $\mathrm{LDH}$ leakage in nicotine treated cell to the level of lipid peroxidation. These results indicate that $\mathrm{LDH}$ release by nicotine may involve another mechanism, in addition to the increase in MDA generation.

The present study concludes that the toxicity and oxidative stress-inducing actions of smokeless tobacco extract are not due entirely to its nicotine content. The mechanisms of toxicities and free radical generation are different in cells treated with nicotine and smokeless tobacco extract containing the same amounts of nicotine. In addition to nicotine, smokeless tobacco extract may constitute other mechanisms for toxicity. Some of the nicotine specific effects could be blocked when present in smokeless tobacco extract. NAC may have an important role in protecting against smokeless tobacco extract-induced cellular damage due to GSH depletion and oxidative stress.

Acknowledgments. This study was supported by the Smokeless Tobacco Research Council, Grant \#0665-01.

\section{References}

Ashakumary L, Vijayammal PL (1996) Effect of nicotine on antioxidant defence mechanisms in rats fed a high-fat diet. Pharmacology 52:153-158

Bagchi D, Hassoun EA, Bagchi M, Stohs SJ (1995) Protective effects of free radical scavengers and antioxidants against smokeless tobacco extract (STE)-induced oxidative stress in macrophage J774A.1 cell culture. Arch Environ Contam Toxicol 29:424-428

Bagchi M, Bagchi D, Stohs SJ (1996) In vitro effects of smokeless tobacco extract on the production of reactive oxygen species by human oral epidermal cells and rat hepatic mitochondria and microsomes, and peritoneal macrophages. Arch Environ Contam Toxicol 30:418-422

Bagchi M, Bagchi D, Adickes E, Stohs SJ (1995) Chronic effects of smokeless tobacco extract on rat liver histopathology and production of HSP-90. J Environ Pathol Toxicol Oncol 14(2):61-68

Benowitz NL (1988) Nicotine and smokeless tobacco. CA-A Cancer J Clin 38:244-247

Bradford MA (1976) Rapid and sensitive method for the quantitation of microgram quantities of protein utilizing the principal of proteindye binding. Anal Biochem 72:248-256

Brunnemann KD, Procopczyk B, Djordevic MV, Hoffmann D (1996) Formation and analysis of tobacco-specific N-nitrosamines. Crit Rev Toxicol 26(2)::121-137

Christen AG, McDanniel RK, McDonald JL Jr (1990) The smokeless tobacco "time bomb." Postgrad Med 87:69-74

Connolly GN, Winn DM, Hecht SS, Hennigfield JE, Walker B, Hoffman D (1986) The reemergence of smokeless tobacco. New Eng J Med 314:1020-1027

Doolittle DJ, Winegar R, Lee CK, Caldwell WS, Hayes AW, deBethizy JD (1995) The genotoxic potential of nicotine and its major metabolites. Mut Res 344:95-102

Draper HH, Squires EJ, Mahmoodi H, Wu J, Agrawal S, Hadley MA (1993) Comparative evaluation of thiobarbutiric acid methods for the determination of malondialdehyde in biological materials. Free Rad Biol Med 15:353-363 
Esterbauer H, Schaur RJ, Zonerr H (1991) Chemistry and biochemistry of 4-hydroxynonenal, malondialdehyde and related aldehyde. Free Rad Biol Med 11:81-128

Gross AJ, Lackland DT, Tu DS (1995) Oral cancer and smokeless tobacco: literature review and meta-analysis. Environ Intl 21:381394

Hahn GM, Shiu EC, Auger EA (1991) Mammalian stress proteins HSP70 and HSP 28 coinduced by nicotine and either ethanol or heat. Mol Cell Biol 11:6034-6040

Hall EJ (1988) Radiobiology for the radiologist, 3d ed. LippincottRaven Publishers, New York, pp 17-37

Hassoun EA, Bagchi D, Bagchi M, Stohs SJ (1995) Effects of vitamin E succinate on smokeless tobacco induced production of nicric oxide by rat peritoneal macrophages and J774A.1 macrophage cells in culture. Free Rad Biol Med 18:577-583

Hoffmann D, Hecht SS (1988) Smokeless tobacco and cancer. ISI Atlas of Science: Pharmacology, American Health Foundation, Valhalla, NY, pp 46-52

Konno S, Oronsky BT, Semproni AR, Wu JM (1991) The effect of nicotine on cell proliferation and synthesis of secreted proteins in BALB/C 3T3 cells. Biochem Intl. 25:7-17

Livingstone GK, Reed RN, Olson BL, Lockey JE (1990) Induction of nuclear aberrations by smokeless tobacco in epithelial cells of human oral mucosa. Environ Mol Mutagen 15:136-144

Neal R (1997) Pro-oxidant effects of $\delta$-aminolevulinic acid ( $\delta$-ALA) on Chinese hamster ovary (CHO) cells. Toxicol Lett 91:169-178

Raisi A, Alipour E, Manouchehri S (1986) Quantitative analysis of nicotine in several cigarette brands available in Iran. Cromatographia 21:711-717

Schievelbein H (1982) Nicotine, resorption and fate. Pharm Ther $18: 233-248$

Tietz NW (1986) Textbook of clinical chemistry. W.B. Saunders Company Philadelphia, pp 691-698

Waggoner SE, Wang X (1994) Effect of nicotine on proliferation of normal, malignant, and human papillomavirus-transformed human cervical cells. Gynecol Oncol 55:91-95

Wetscher GJ, Bagchi M, Bagchi D, Perdikis G, Hinder PR, Glaser K, Hinder RA (1995a) Free radical production in nicotine treated pancreatic tissue. Free Rad Biol Med 18:877-882

Wetscher GJ, Bagchi D, Perdikis G, Bagchi M, Redmond EJ, Hinder PR, Glaser K, Hinder RA (1995b) In vitro free radical production in rat esophageal mucosa induced by nicotine. Dig Dis Sci 40:853-858

Yildiz D, Ercal N, Armstrong DW (1998) Nicotine enantiomers and oxidative stress. Toxicology 130:155-165 